\title{
Relationship between Index Leaf Nutrient Concentration Yield and Quality of Byadgi Chilli (Capsicum annuum L.) Influenced by Calcium Nitrate Foliar Application
}

\author{
Kavitha P. Jadhav ${ }^{*}$, B.I. Bidari ${ }^{2}$, G.B. Shashidara ${ }^{3}$, \\ M.S. Venkatesh ${ }^{4}$ and A. Naveenkumar ${ }^{1}$ \\ ${ }^{1}$ Division of Soil Science and Agricultural Chemistry, Indian Agricultural Research Institute, \\ Delhi, India \\ ${ }^{2}$ Division of Soil Science and Agricultural Chemistry, ${ }^{3}$ Division of Agronomy, University of \\ Agricultural Sciences Dhaward, Karnataka, India \\ ${ }^{4}$ Indian Institute of Pulses Research (ICAR), Regional Research Centre, UAS, Dharwad \\ Karnataka, India \\ *Corresponding author
}

A B S T R A C T

\begin{tabular}{|l|}
\hline Ke y w or d s \\
Calcium Nitrate, \\
$\begin{array}{l}\text { Chilli, Colour } \\
\text { value, Oleoresin, } \\
\text { Yield }\end{array}$ \\
\hline Article Info \\
\hline $\begin{array}{l}\text { Accepted: } \\
\text { 20 June } 2019 \\
\text { Available Online: } \\
\text { 10 July } 2019\end{array}$ \\
\hline
\end{tabular}

A field experiment was undertaken in the farmer's field at Agadi village (Tq., Hubbli) in Dharwad district Karnataka India to investigate the relationship between index leaf nutrient concentration, yield and quality of Byadgi chilli influenced by calcium nitrate foliar spray. Two different concentration of calcium nitrate was foliar sprayed at different stages of chilli crop (1.0 and $1.5 \% \mathrm{Ca}\left(\mathrm{NO}_{3}\right)_{2}$ and the experimental plot was laid out in randomized complete block design (RCBD) with twelve treatments and three replications. Result revealed that yield and quality attributes of chillies did not show any relationship with concentration of nutrients in index leaves before foliar spray of $\mathrm{Ca}\left(\mathrm{NO}_{3}\right)_{2}$ on 60 DAT but after foliar spray. Calcium content of index leaf showed significant positive correlation with yield $(0.632 *)$ and colour value $(0.702 *)$ and no relationship with oleoresin content. After spray at 75 DAT yield and quality attributes of red chillies were significantly and positively influenced by nutrient content of chilli leaves. But there is no correlation of $\mathrm{P}$ and $\mathrm{Mg}$ with yield and colour value. Foliar spray at 60 DAT closely synchronized with flower dropping and also colour development and oleoresin content in chilli fruits.

\section{Introduction}

Chilli (Capsicum annuum L.) is chief use throughout the world is as a spice on account of its pungency, oleoresin, essential oil and chilli powder have gained greater importance in the global market than whole chilli. Chilli is usually grown as rainfed crop especially for 
red dry fruits on medium black soils of Dharwad and Haveri districts of Karnataka, India. Chilli belongs to the family Solanaceae, native of South America and domesticated in Mexico from ancient times. Though twenty wild species of chillies have been reported, only two species are extensively cultivated in India viz., $C$. annuum and $C$. fruitescens. Chillies were introduced to India by Portuguese during 17th century. Chillies are cultivated mainly in tropical and subtropical countries and the leading producers are Africa, India, Japan, Mexico, Turkey, Korea and USA. posses unique property of high colour value and low pungency with characteristic flavor and hence have export value.

According to Gross (1991) red colour in chillies is due to two major carotenoides viz. capsanthin (30 to $60 \%$ ) and capsorubin (6 to $18 \%)$. Ninty nine per cent of red colour in chillies is concentrated in pericarp. Oleoresin is the true essence of spice and can replace whole or ground spices without impairing their flavour and aroma (Sivaraman et al., 2001). Oleoresin represents the complete flavour of the spice and contains both volatile and nonvolatile components. In recent years the yield of Byadgi chillies is declining because of inadequate nutrition and disease attack and reducing the export quality. In Karnataka, chilli is being grown on an area of 1.56 lakh hectares with a production of 0.895 lakh tonnes. In north Karnataka, chilli occupies 13.76 per cent of area, 1.12 lakh tones of production and $12.51 \mathrm{q} \mathrm{ha}{ }^{-1}$ of productivity. Calcium is one of the most critical secondary nutrients that is vital for the growth and strength of the plants body. Lack of Calcium produces a general breakdown of cell membrane structures with resultant loss in retention of cellular diffusible compounds and results in flower and fruit drop. Use of Calcium nitrate is popular in agronomic situations where a readily soluble source of nitrate and calcium as it contains 18.8 per cent calcium and 15.5 per cent nitrogen. Calcium enhances uptake of $\mathrm{NO}_{3}-\mathrm{N}$ and interrelated with nitrogen metabolism. But the concentration and frequency of foliar spray is not studied. Hence, the present investigation was planned with the objective "Effect of foliar application of calcium nitrate on the growth, nutrient concentration in index leaf and yield of Byadgi chilli".

\section{Materials and Methods}

The experiment was conducted in farmer's field (Survey No. 88) at Agadi village (Tq: Hubli) in Dharwad district Karnataka Inida. Agadi village is situated in the northern transitional zone (Zone-8) of Karnataka with a latitude of $15^{\circ} 10^{\prime} 46.5^{\prime}$ ' North and a longitude of $75^{\circ} 10^{\prime} 01.5^{\prime}$, East. The soil of the experimental site is Vertisol (medium black soil).The experiment was laid out in Randomized Complete Block Design (RCBD) with three replications and 12 treatments.

The soil was deep black in colour with soil $\mathrm{pH}$ (7.30), EC (0.26 dS m$\left.{ }^{-1}\right)$, organic carbon (6.90 $\left.\mathrm{g} \mathrm{kg}^{-1}\right)$, cation exchange capacity (45.61 cmol $\left.\left(\mathrm{p}^{+}\right) \mathrm{kg}^{-1}\right)$, free $\mathrm{CaCO}_{3}(2.5 \%)$, available nitrogen $\left(180.65 \mathrm{kgha}^{-1}\right)$, available phosphorus (16.85 $\mathrm{P}_{2} \mathrm{O}_{5} \mathrm{~kg} \mathrm{ha} \mathrm{kg}^{-1}$ ), available potassium (282.24 $\left.\mathrm{K}_{2} \mathrm{O} \mathrm{kg} \mathrm{ha}{ }^{-1}\right)$, available sulphur (20.25 $\left.\mathrm{kg} \mathrm{ha}{ }^{-1}\right)$, exchangeable calcium (14.50 cmol $\left.\left(\mathrm{p}^{+}\right) \mathrm{kg}^{-1}\right)$, exchangeable magnesium (5.50 cmol $\left.\left(\mathrm{p}^{+}\right) \mathrm{kg}^{-1}\right)$. There were nine treatment combinations which are given below in Table 1.

Nitrogen was supplied partly through DAP and urea, while, the entire doses of phosphorous and potassium were supplied through DAP and murite of potash, respectively. Nitrogen was applied in two split doses, basal dose of 50 per cent at the time of transplanting and remaining 50 per cent at 45 DAT after transplanting. The fertilizers were applied in ring method and mixed well with 
soil. Recommended doses NPK fertilizers (100:50:50 $\mathrm{kg} \mathrm{ha}^{-1}$ ) and $25 \mathrm{t} \mathrm{ha}^{-1}$ FYM was applied in common to all treatments.

\section{Results and Discussion}

Yield and quality attributes of chillies did not show any relationship with concentration of nutrients $(\mathrm{N}, \mathrm{P}, \mathrm{K}, \mathrm{S}, \mathrm{Ca}$ and $\mathrm{Mg}$ ) in index leaves before foliar spray of $\mathrm{Ca}\left(\mathrm{NO}_{3}\right)_{2}$ on 60 DAT.

This is because of inadequate supply of $\mathrm{Ca}$ through $\mathrm{Ca}\left(\mathrm{NO}_{3}\right)_{2}$ and one spray given on 45 DAT might have been completely utilized by the plants and there might be deficiency of $\mathrm{Ca}$ in terminal parts of the plants due to dilution. However, yield and colour value possessed closer relationship with nutrient concentration in leaves than oleoresin.

Yield and colour value of red chilli fruits possessed significant positive relationship with nitrogen, phosphorus, sulphur and calcium content of index leaves. But only colour value of fruits possessed significantly positive correlation with potassium and magnesium content of index leaves. This might be due to higher uptake of $\mathrm{K}$ from soil and also due to the role of $\mathrm{K}$ in balancing acid: sugar ratio in fruits with greater accumulation of sugars leading to enhanced red colour (Somimol, 2012). Further P and S content of index leaf possessed significant positive correlation with colour value $\left(0.700^{*}\right.$ and $0.791 * *)$. This might be due to synergestic interaction of $\mathrm{Ca}$ and $\mathrm{N}$ with leaf $\mathrm{P}$ and $\mathrm{S}$ that increased phosphorus and sulphur content in leaves which enhances sugar content. It is known that, phosphorus is involved in glycolysis pathway and the end product of this pathway is glucose. Hence, increased sugar content resulted in increased colour value. $\mathrm{Mg}$ also has a positive correlation with yield and colour might be due to the synergestic relationship between $\mathrm{Mg}$ and $\mathrm{N}$ content in index leaf supplied through $\mathrm{Ca}(\mathrm{NO} 3) 2$. Ca concentration of index leaf had positive correlation with colour value because of the role of $\mathrm{Ca}$ in increasing the $\mathrm{K}$ uptake by plant. Kolay, (2000) reported that increased supply of $\mathrm{Ca}$ to the plant indirectly enhances $\mathrm{K}$ uptake by the plant, hence increased $\mathrm{K}$ uptake favours yield and colour value of fruits.

Data indicated that, yield and colour value of fruits were significantly and positively correlated with leaf nitrogen content $(0.798 *)$. This might be due to role of nitrogen in photosynthesis, and translocation of photosynthates to developing fruits leading to higher yield. There is a synergestic relationship between $\mathrm{N}$ and $\mathrm{K}$ (Das, 2007) and nitrate nitrogen supplied through foliar spray of calcium nitrate enhances $\mathrm{K}$ uptake from soil. This absorbed $\mathrm{K}$ helps in colour development of chilli fruits (Bidari, 2000 and Somimol, 2012). Foliar spray at 75 DAT has closely synchronized with flower dropping and $\mathrm{Ca}$ supplied through $\mathrm{Ca}(\mathrm{NO} 3) 2$ gives assimilates in pedicel of flowers leading to reduced flower drop which causes increased fruit yield.

The yield and quality attributes of red chillies were significantly and positively influenced by the nitrogen, phosphorus, potassium, sulphur, calcium and magnesium concentration of index leaf after foliar spray of $\mathrm{Ca}\left(\mathrm{NO}_{3}\right)_{2}$ at $75 \mathrm{DAT}$. Fruit yield of chillies possessed positive and significant correlation with nitrogen $\left(0.658^{*}\right)$, sulphur $(0.641 *)$ and calcium content of index leaves, whereas, phosphorous, potassium and magnesium were not related to fruit yield. Similarly, colour value of chilli fruits bears positive and significant relationship nitrogen $\left(0.681^{*}\right)$, potassium $\left(0.691^{*}\right)$, sulphur $\left(0.633^{*}\right)$ and calcium $\left(0.671^{*}\right)$ contents of index leaves. Lastly oleoresin content of fruits possessed positive and significant relationship with all nutrients except potassium (Table 2-5). 
Table.1

\begin{tabular}{|l|}
\hline Treatments details \\
\hline$T_{1}-1.0 \% \mathrm{Ca}\left(\mathrm{NO}_{3}\right)_{2}$ foliar spray at $45 \mathrm{DAT}$ \\
\hline $\mathrm{T}_{2}-1.0 \% \mathrm{Ca}\left(\mathrm{NO}_{3}\right)_{2}$ foliar spray at $60 \mathrm{DAT}$ \\
\hline $\mathrm{T}_{3}-1.0 \% \mathrm{Ca}\left(\mathrm{NO}_{3}\right)_{2}$ foliar spray at $75 \mathrm{DAT}$ \\
\hline $\mathrm{T}_{4}-1.0 \% \mathrm{Ca}\left(\mathrm{NO}_{3}\right)_{2}$ foliar spray at $45+60 \mathrm{DAT}$ \\
\hline $\mathrm{T}_{5}-1.0 \% \mathrm{Ca}\left(\mathrm{NO}_{3}\right)_{2}$ foliar spray at $45+60+75 \mathrm{DAT}$ \\
\hline $\mathrm{T}_{6}-1.5 \% \mathrm{Ca}\left(\mathrm{NO}_{3}\right)_{2}$ foliar spray at $45 \mathrm{DAT}$ \\
\hline $\mathrm{T}_{7}-1.5 \% \mathrm{Ca}\left(\mathrm{NO}_{3}\right)_{2}$ foliar spray at $60 \mathrm{DAT}$ \\
\hline $\mathrm{T}_{8}-1.5 \% \mathrm{Ca}\left(\mathrm{NO}_{3}\right)_{2}$ foliar spray at $75 \mathrm{DAT}$ \\
\hline $\mathrm{T}_{9}-1.5 \% \mathrm{Ca}\left(\mathrm{NO}_{3}\right)_{2}$ foliar spray at $45+60 \mathrm{DAT}$ \\
\hline$T_{10}-1.5 \% \mathrm{Ca}\left(\mathrm{NO}_{3}\right)_{2}$ foliar spray at $45+60+75 \mathrm{DAT}$ \\
\hline$T_{11}-50$ ppm NAA at peak flowering stage $(60 \mathrm{DAT})$ \\
\hline$T_{12}-\mathrm{Control}(\mathrm{water}$ spray at 45, 60 and $75 \mathrm{DAT})$ \\
\hline
\end{tabular}

Table.2 Relationship of yield and quality attributes of red chilli fruits with nutrients concentration of index leaf in chilli at 60 DAT before spray

\begin{tabular}{|l|c|c|c|}
\hline Nutrient concentration & Yield (q/ha) & Colour value (ASTA units) & Oleoresin (\%) \\
\hline Nitrogen & 0.402 & 0.534 & 0.100 \\
\hline Phosphorous & 0.500 & 0.468 & 0.249 \\
\hline Potassium & 0.370 & 0.439 & 0.355 \\
\hline Sulphur & 0.472 & 0.548 & 0.117 \\
\hline Calcium & 0.290 & 0.524 & 0.134 \\
\hline Magnesium & 0.259 & 0.587 & -0.015 \\
\hline
\end{tabular}

Table.3 Relationship of yield and quality attributes of red chilli fruits with nutrients concentration of index leaf in chilli at 60 DAT after spray

\begin{tabular}{|l|c|c|c|}
\hline \multicolumn{1}{|c|}{ Nutrient concentration } & Yield $\left(\mathbf{q} / \mathbf{h a}^{-\mathbf{1}}\right)$ & Colour value (ASTA units) & Oleoresin $(\mathbf{\%})$ \\
\hline Nitrogen & $0.671^{*}$ & $0.700^{*}$ & 0.102 \\
\hline Phosphorous & $0.552^{*}$ & $0.700^{*}$ & 0.304 \\
\hline Potassium & 0.347 & $0.646^{*}$ & 0.354 \\
\hline Sulphur & $0.595^{*}$ & $0.791^{*}$ & 0.131 \\
\hline Calcium & $0.632^{*}$ & $0.702^{*}$ & 0.179 \\
\hline Magnesium & 0.303 & $0.668^{*}$ & -0.210 \\
\hline
\end{tabular}

Table.4 Relationship of yield and quality attributes of red chilli fruits with nutrients concentration of index leaf in chilli at 75 DAT before spray

\begin{tabular}{|l|c|c|c|}
\hline \multicolumn{1}{|c|}{ Nutrient concentration } & Yield $(\mathbf{q} / \mathbf{h a})$ & Colour value (ASTA units) & Oleoresin $(\boldsymbol{\%})$ \\
\hline Nitrogen & $0.798^{*}$ & $0.667^{*}$ & 0.237 \\
\hline Phosphorous & $0.540^{*}$ & $0.681^{*}$ & 0.283 \\
\hline Potassium & 0.370 & $0.650^{*}$ & 0.418 \\
\hline Sulphur & $0.598^{*}$ & $0.784^{* *}$ & 0.128 \\
\hline Calcium & $0.669^{*}$ & $0.719^{* *}$ & 0.330 \\
\hline Magnesium & 0.297 & $0.794^{* *}$ & 0.213 \\
\hline
\end{tabular}


Table.5 Relationship of yield and quality attributes of red chilli fruits with nutrients concentration of index leaf in chilli at 75 DAT after spray

\begin{tabular}{|l|c|c|c|}
\hline Nutrient concentration & Yield $(\mathbf{q} / \mathbf{h a})$ & Colour value (ASTA units) & Oleoresin $(\%)$ \\
\hline Nitrogen & $0.658^{*}$ & $0.681^{*}$ & $0.680^{*}$ \\
\hline Phosphorous & 0.454 & 0.402 & $0.722^{* *}$ \\
\hline Potassium & 0.255 & $0.691 *$ & 0.443 \\
\hline Sulphur & $0.641^{*}$ & $0.633^{*}$ & $0.603 *$ \\
\hline Calcium & $0.586^{*}$ & $0.671 *$ & $0.768^{* *}$ \\
\hline Magnesium & 0.441 & 0.398 & $0.661 *$ \\
\hline
\end{tabular}

Foliar spray at 60 DAT closely synchronized with flower dropping and also colour development and oleoresin content in chilli fruits.

Foliar spray of $\mathrm{Ca}\left(\mathrm{NO}_{3}\right)_{2}$ enhanced the concentration of $\mathrm{Ca}$ and $\mathrm{N}$ in leaves.

Increased $\mathrm{Ca}$ content in leaves stimulated $\mathrm{K}$ uptake by plant roots because of synergestic relationship between $\mathrm{Ca}$ and $\mathrm{K}$.

The absorbed $\mathrm{K}$ gets translocated to developing fruits and helps in rapid transformation chloroplast to chromoplast by increasing sugar synthesis in chilli fruits.

The increased nitrogen content in chilli leaves participates in leaf chlorophyll synthesis leading to increased photosynthesis and contributing to higher fruit yield.

Yield and quality attributes of chilli fruits were significantly and positively correlated with nutrients concentration of index leaves after foliar spray of $\mathrm{Ca}\left(\mathrm{NO}_{3}\right)_{2}$ at 60 and 75 DAT.

Three foliar sprays of 1.5 per cent $\mathrm{Ca}\left(\mathrm{NO}_{3}\right)_{2}$ one each at 45th,60th and 75th day after transplanting significantly improved the yield, colour value and oleoresin content of Byadgi chilli over NAA foliar spray and control. This showed that three sprays of 1.5 per cent $\mathrm{Ca}\left(\mathrm{NO}_{3}\right)_{2}$ influenced quality and yield of chilli than 1.0 per content $\mathrm{Ca}(\mathrm{NO} 3) 2$, NAA spray and farmer practices.

\section{References}

Bidari, B. I., 2000, Studies on yield and quality of Byadgi chilli (Capsicum annuum L.) in relation to soil properties in transitional zone and part of dry zone of North Karnataka. Ph. D. Thesis, Univ. Agri. Sci., Dharwad.

Gross, J., 1991, Pigments in Vegetables Chlorophylls and Carotenoids. Van Nostrand Reinhold, New York, pp.112141.

Kolay, A. K., 2000, Basic Concepts of Soil Science - second edition. New Age International Private limited Publishers, New Delhi, p. 209.

Sivaraman, K., Tamilselvan, M. and Elizabeth, K. G., 2001, Value addition in seed spices. Indian J. Arecanut, Spices and Medicinal Plant, 3: 187-190.

Somimol, P. V., 2012, Effect of foliar spray of 19: 19: 19 and KNO3 water soluble fertilizers on growth parameters of byadgichillli. M. Sc. (Agri.) Thesis, Univ. Agric. Sci., Dharwad, Karnataka (India). 


\section{How to cite this article:}

Kavitha P. Jadhav, B. I. Bidari, G. B. Shashidara, M. S. Venkatesh and Naveenkumar, A. 2019. Relationship between Index Leaf Nutrient Concentration Yield and Quality of Byadgi Chilli (Capsicum aпnиит L.) Influenced by Calcium Nitrate Foliar Application. Int.J.Curr.Microbiol.App.Sci. 8(07): 2575-2580. doi: https://doi.org/10.20546/ijcmas.2019.807.317 